\title{
Association of flowering time with phenological and productivity traits in chickpea
}

\author{
Bingi Pujari Mallikarjuna $\cdot$ Kannalli P. Viswanatha $\cdot$ Srinivasan Samineni \\ Pooran M. Gaur $\mathbb{B}$
}

Received: 7 August 2018/Accepted: 8 March 2019

(C) Springer Nature B.V. 2019

\begin{abstract}
Phenology is an important trait for the adaption of chickpea (Cicer arietinum L.) to various target environments. The aim of this study was to determine the effects of flowering time on other phenological traits and yield-related traits. $\mathrm{F}_{2}$ and $\mathrm{F}_{3}$ segregating populations derived from the crosses of four early-flowering lines (ICCV 96029, ICC 5810, BGD 132 and ICC 16641) with a late-flowering cultivar (CDC Frontier) were used. In all crosses, flowering time showed significant positive association with days to pod initiation, days to maturity, plant height and biomass and non-significant correlation with number of pods per plant, number of seeds per plant and grain yield per plant. Flowering time had a positive correlation with 100-seed weight in all crosses, with the exception of ICC $16641 \times$ CDC Frontier where the correlation was non-significant. Harvest index was negatively associated with flowering time. In most of the crosses, early- and late-
\end{abstract}

B. P. Mallikarjuna · S. Samineni · P. M. Gaur ( $\square)$ International Crops Research Institute for the Semi-Arid Tropics (ICRISAT), Patancheru, Hyderabad,

Telangana 502324, India

e-mail: p.gaur@cgiar.org

B. P. Mallikarjuna · K. P. Viswanatha University of Agricultural Sciences, Raichur, Karnataka, India

P. M. Gaur

The UWA Institute of Agriculture, University of Western Australia, Perth, WA 6009, Australia maturing $\mathrm{F}_{3}$ bulks showed significant differences with respect to biomass and harvest index, while for grain yield and 100-seed weight the differences were found to be non-significant. These results indicate that flowering time could be used as a reliable selection criterion in breeding for early-maturing chickpea and that a reduction in the duration of flowering time and maturity may not necessarily have a yield penalty in these genetic backgrounds.

Keywords Cicer arietinum - Correlation coefficient $\cdot$ Early maturity $\cdot$ Grain yield

\section{Introduction}

Chickpea (Cicer arietinum L.; $2 n=2 x=16$ ) is the second most important food legume globally and a staple protein crop in the Indian subcontinent. It is cultivated in more than 50 countries worldwide, over an area of 12.6 million hectares, with a total production of 12.1 million tonnes and average yield of $956 \mathrm{~kg} / \mathrm{ha}$ (FAOSTAT 2016). Being a highly nutritious food legume (Jukanti et al. 2012), chickpea also improves soil nutritional status by fixing atmospheric nitrogen through symbiotic nitrogen fixation. Chickpea is traditionally a low-input crop, and about $80 \%$ of the world's chickpea crop is grown in the areas relying on conserved soil moisture conditions where the crop often experiences terminal drought stress (Gaur et al. 2008b). 
Based on research undertaken in India and other countries, early phenology (time to flowering, podding and maturity) has been identified as a key trait for the adaption of chickpea to different growing environments (Kumar and Abbo 2001; Berger et al. 2006; Gaur et al. 2008a, b, 2018). Early maturity helps the crop escape end-of-season stresses, such as drought (Subbarao et al. 1995) and frost (Anbessa et al. 2006), thereby increasing and stabilizing chickpea yields in short-season environments. Consequently, breeding for early maturity has been one of the major chickpea breeding objectives in recent years. The duration of crop maturity is the end result of several phenological and morphological variables, which are interrelated and could be manipulated separately. Breeders generally have used days to flowering as a key indicator of maturity duration since this trait provides a good indication of subsequent phenological traits, such as time of podding and maturity in chickpea (Gaur et al. 2015).

To date, major genes controlling flowering time have been reported in chickpea lines ICCV 96029 (Kumar and van Rheenen 2000), ICC 5810 (Or et al. 1999), BGD 132 (Hegde 2010) and ICC 16641 (Gaur et al. 2015), and the corresponding genomic regions have been recently identified (Mallikarjuna et al. 2017). This simple genetic basis of major flowering time genes facilitates introgression into any popular late-flowering genetic background by simple backcrossing. However, breeding programs aimed at early maturity should also consider other important agronomic traits to exploit additional gains (Hovav et al. 2003). Also, it would be of interest to know the association of these early-flowering genes with other phenological traits as well as with other component traits of productivity. Such information will be useful to breeders in developing early maturing varieties with other desired traits. Therefore, the aim of this study was to examine the relationships of flowering time with other phenological and yield-related traits in four chickpea crosses.

\section{Materials and methods}

\section{Experimental material}

The study described herein was conducted at the International Crops Research Institute for Semi-Arid Tropics (ICRISAT), Patancheru, India. The experimental material was developed by crossing four early-flowering lines, namely, ICCV 96029, ICC 5810, BGD 132 and ICC 16641 (for detailed characteristics, see Gaur et al. 2015) with a late-flowering cultivar, CDC Frontier (Warkentin et al. 2005). A total of $190 \mathrm{~F}_{2}$ plants in each of the three crosses, ICCV $96029 \times$ CDC Frontier, ICC $5810 \times$ CDC Frontier and BGD $132 \times \mathrm{CDC}$ Frontier, and $146 \mathrm{~F}_{2}$ plants in the cross ICC $16641 \times$ CDC Frontier were evaluated during the post-rainy season of 2013-2014 along with their parents and $F_{1} s$. Observations were recorded on each plant on flowering time, days to pod initiation, days to maturity, plant height, number of pods per plant, number of seeds per plant, grain yield per plant, 100-seed weight, biomass per plant and harvest index. Simple correlation coefficients between flowering time and other traits were calculated using Microsoft Excel 2013 (Microsoft Corp., Redmond, WA, USA).

During the crop season 2014-2015, a total of 164, 174,182 and $102 \mathrm{~F}_{3}$ progenies from the crosses ICCV $96029 \times$ CDC Frontier, ICC $5810 \times$ CDC Frontier, BGD132 $\times$ CDC Frontier and ICC $16641 \times$ CDC Frontier, respectively, were raised. Each $\mathrm{F}_{3}$ progeny row was observed for flowering time at regular intervals and classified as non-segregating (uniform early or late flowering) and segregating types. Observations such as flowering time, days to maturity, grain yield, biomass, 100-seed weight and harvest index (calculated) were recorded on 1-m continuous rows of uniform early- and late-flowering segregants. Statistical procedures, including descriptive statistics and student $t$ test, were performed to compare the means of early- and late-flowering groups using Microsoft Excel 2013.

\section{Results and discussion}

Mean performance of parental lines for flowering time and other important traits

The female parents, i.e. ICCV 96029, ICC 5810, BGD 132 and ICC 16641, took 27, 28, 29 and 29 days to flowering, 33, 38, 35 and 35 days to pod initiation and $76,77,79$ and 79 days to maturity after sowing, respectively (Table 1). In comparison, the male parent CDC Frontier was very late in days to flowering (67 days), pod initiation (72 days) and maturity (108 days). The mean plant height among the early-flowering lines 


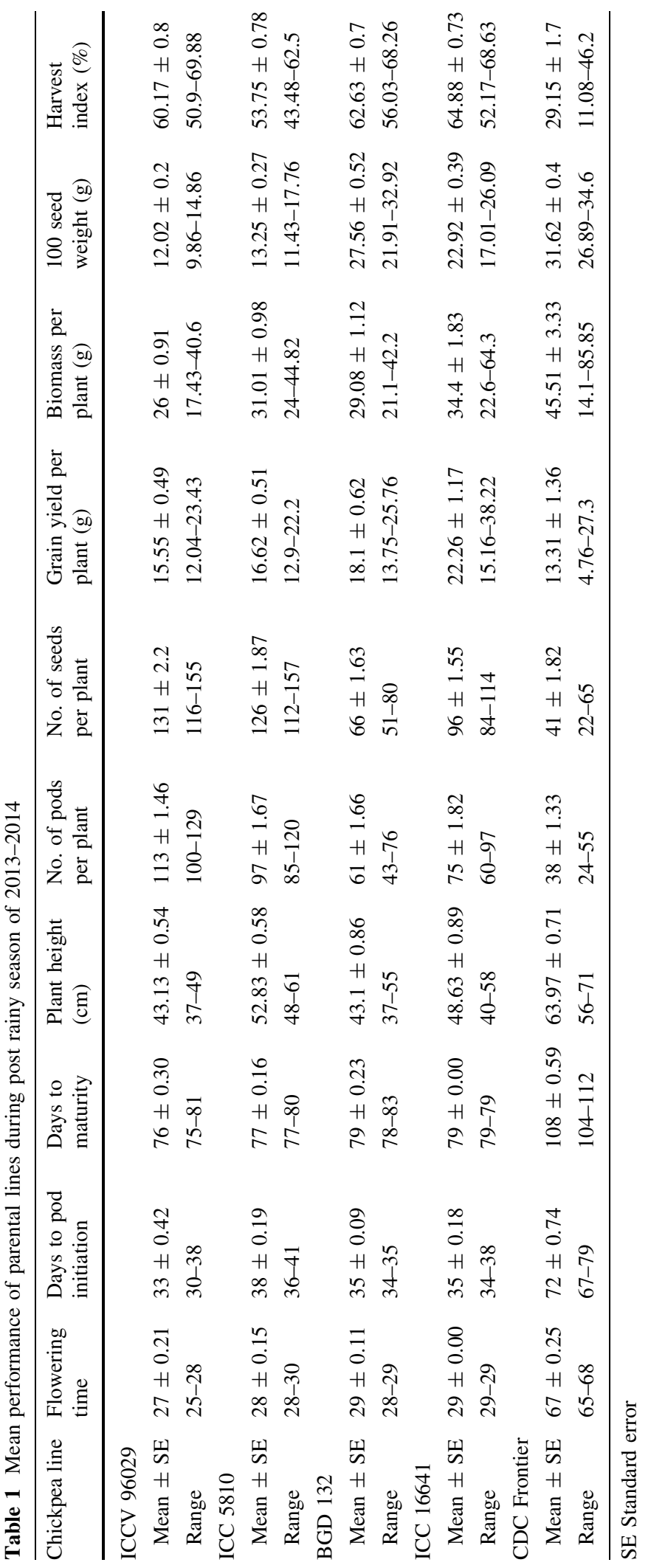


ranged from 43.1 (ICCV 96029) to $52.8 \mathrm{~cm}$ (ICC 5810), whereas mean recorded plant height of CDC Frontier was $64.0 \mathrm{~cm}$. Among the early-flowering lines, the highest number of pods per plant (113.3) and highest number of seeds per plant (130.6) were recorded for ICCV 96029, while BGD 132 was found to have the lowest number of pods per plant (60.9) and lowest number of seeds per plant (66.4). For CDC Frontier, the mean number of pods per plant was 37.9 and the mean number of seeds per plant was 41.8. Among the earlyflowering lines, ICC 16641 was found to have the highest grain yield per plant (22.3 g) and highest biomass per plant (34.4 g), while ICCV 96029 had the lowest grain yield per plant $(15.6 \mathrm{~g})$ and lowest biomass per plant (26 g). The late-flowering line CDC Frontier recorded grain yield per plant of $13.3 \mathrm{~g}$ with $45.5 \mathrm{~g}$ biomass per plant. Hundred seed weight among the early-flowering lines ranged from 12.0 (ICCV 96029) to $27.6 \mathrm{~g}$ (BGD 132), while that of the late-flowering line CDC Frontier was $31.62 \mathrm{~g}$. The harvest index of the early-flowering lines ranged from 53.8 (ICC 5810) to 64.9\% (BGD 132), while that of CDC Frontier was $29.2 \%$. These results clearly indicate that there is significant difference between the early- and late-flowering lines with respect to phenology and other traits.

Association between flowering time and other agronomic traits

The data collected on individual $\mathrm{F}_{2}$ plants were used to estimate correlation coefficients between flowering time and other agronomic traits in all the crosses (Table 2). Flowering time exhibited a positive significant correlation with days to pod initiation in all crosses (ICCV $96029 \times$ CDC Frontier, $r=0.99$; ICC $5810 \times \mathrm{CDC}$ Frontier, $r=0.99 ; \quad \mathrm{BGD}$ $132 \times$ CDC Frontier, $r=0.99$; ICC $16641 \times$ CDC Frontier, $r=0.99$ ), suggesting that early flowering leads to early podding in these crosses. Also in all crosses, flowering time and days to maturity exhibited highly significant positive correlation $(r=0.88$, $r=0.89, r=0.93$ and $r=0.95$, respectively). These results indicate that in general early-flowering lines also mature early. It appears that flowering time influenced maturity duration in chickpea mainly through its effect on days to pod initiation. Therefore, flowering time would appear to be the more precise trait to record than days to maturity to discriminate between early and late genotypes under conditions where the recording of maturity is influenced by environmental factors such as available soil moisture and temperature. However, effective manipulation of final maturity duration would best be achieved by selecting for more than one component of crop duration (Anbessa et al. 2006).

Flowering time showed significant positive correlation with plant height in all crosses (ICCV $96029 \times$ CDC Frontier, $r=0.51$; CC $5810 \times$ CDC Frontier, $\quad r=0.19$; BGD $132 \times \mathrm{CDC}$ Frontier, $r=0.45 ; \quad$ ICC $16641 \times$ CDC Frontier, $r=0.47$ ) and biomass $(r=0.26, \quad r=0.18, \quad r=0.33$ and $r=0.28)$. A similar type of correlation has been

Table 2 Correlation coefficients between flowering time and other important traits observed in different $F_{2}$ populations

\begin{tabular}{|c|c|c|c|c|c|c|c|c|c|}
\hline Cross & $\begin{array}{l}\text { Days to pod } \\
\text { initiation }\end{array}$ & $\begin{array}{l}\text { Days to } \\
\text { maturity }\end{array}$ & $\begin{array}{l}\text { Plant } \\
\text { height }\end{array}$ & $\begin{array}{l}\text { Pods } \\
\text { per } \\
\text { plant }\end{array}$ & $\begin{array}{l}\text { Seeds } \\
\text { per } \\
\text { plant }\end{array}$ & $\begin{array}{l}\text { Biomass } \\
\text { per plant } \\
(\mathrm{g})\end{array}$ & $\begin{array}{l}\text { Grain yield } \\
\text { per plant }(\mathrm{g})\end{array}$ & $\begin{array}{l}100 \text { Seed } \\
\text { weight }(\mathrm{g})\end{array}$ & $\begin{array}{l}\text { Harvest } \\
\text { index }\end{array}$ \\
\hline $\begin{array}{l}\text { ICCV } \\
96029 \times \mathrm{CDC} \\
\text { Frontier }\end{array}$ & $0.99 * *$ & $0.88 * *$ & $0.51 * *$ & -0.03 & -0.05 & $0.26 * *$ & 0.05 & $0.28 * *$ & $-0.43 * *$ \\
\hline $\begin{array}{l}\text { ICC } \\
5810 \times \mathrm{CDC} \\
\text { Frontier }\end{array}$ & $0.99 * *$ & $0.89 * *$ & $0.19 * *$ & -0.09 & -0.13 & $0.18 *$ & -0.01 & $0.31 * *$ & $-0.44 * *$ \\
\hline $\begin{array}{l}\text { BGD } \\
132 \times \mathrm{CDC} \\
\text { Frontier }\end{array}$ & $0.99 * *$ & $0.93 * *$ & $0.45 * *$ & 0.13 & 0.09 & $0.33 * *$ & 0.13 & $0.24 * *$ & $-0.49 * *$ \\
\hline $\begin{array}{l}\text { ICC } \\
16641 \times \mathrm{CDC} \\
\text { Frontier }\end{array}$ & $0.99 * *$ & $0.95 * *$ & $0.47 * *$ & -0.05 & -0.09 & $0.28^{*}$ & -0.09 & -0.06 & $-0.62 * *$ \\
\hline
\end{tabular}

*Correlation is significant at the 0.05 level; **correlation is significant at the 0.01 level 
reported earlier in chickpea (Bonfil et al. 2006), pea and lentil (Slinkard and Sindhu 1988; Erskine et al. 2000). The nature of this association would appear to be that late-flowering genotypes had more time for vegetative growth (growing taller and accumulating higher biomass) compared to extra-early and early plants.

A non-significant correlation was found in all crosses for flowering time with number of pods per plant, number of seeds per plant and grain yield per plant. Several causes for the lack of a simple relationship between these traits are possible. One underlying cause could be that the common male parent in all crosses, CDC Frontier, is a very latematuring line but a poor yielder under the growing conditions of Patancheru compared to all of the extraearly female lines (Table 1). These results suggest that selection for early flowering (to a certain extent) need not necessarily involve a severe yield penalty in earlymaturing genotypes as the possibility of combining components of earliness with yield-promoting alleles has been demonstrated in desi chickpea (Siddique and Khan 1996).

A weak positive correlation was observed between flowering time and 100-seed weight in the crosses ICCV $96029 \times$ CDC Frontier $(r=0.28), \quad$ ICC $5810 \times \mathrm{CDC}$ Frontier $(r=0.31)$ and BGD $132 \times$ CDC Frontier $(r=0.24)$, whereas, a nonsignificant correlation was observed in ICC $16641 \times$ CDC Frontier. A significant and positive correlation between time to flowering and seed weight was also reported by Hovav et al. (2003), suggesting that in certain genetic backgrounds it might be difficult to breed early-flowering cultivars without compromising seed size. On the other hand, Gaur et al. (2015) observed a non-significant correlation between flowering time and mean seed weight in early-flowering segregants in the crosses where ICCV 96029 (efl-1), ICC 5810 (efl-2), BGD 132 (efl-3) and ICC 16641 (efl4 ) were used as parents. These findings highlight the notion that under certain genetic backgrounds, there is scope for combining earliness with large seed size in chickpea.

Flowering time exhibited a significant negative correlation with harvest index in all the crosses (ICCV $96029 \times$ CDC Frontier, $r=-0.43$; ICC $5810 \times$ CDC Frontier, $r=-0.44$; BGD $132 \times$ CDC Frontier, $r=-0.49$; ICC $16641 \times$ CDC Frontier, $r=$ -0.62 ). This negative correlation indicates that the extra-early and early genotypes were more efficient in partitioning their yield and accumulating the biomass necessary to ensure optimum seed yield within a shorter duration, possibly through a higher crop growth rate and growth vigor. The genomic regions identified for plant vigor was found to be the quantitative trait locus hotspot contributing drought tolerance in chickpea (Sivasakthi et al. 2018). These characteristics would be useful for stabilizing yield under short-season environments. The results are consistent with the widely believed hypothesis that early maturity is associated with a high harvest index (Wallace et al. 1993; Anbessa et al. 2007). A high harvest index and drought escape through early flowering and early maturity are considered to be important attributes of adaptation in chickpea under environments prone to drought stress (Berger et al. 2004).

Effect of flowering time on productivity traits

To quantify the effect of flowering time on maturity, grain yield, biomass, harvest index and seed size, we performed $t$ tests between the early- and late-flowering $\mathrm{F}_{3}$ progenies of all the crosses (Table 3; Fig. 1). In the crosses ICCV $96029 \times$ CDC Frontier, ICC $5810 \times$ CDC Frontier, BGD $132 \times$ CDC Frontier and ICC $16641 \times$ CDC Frontier, the mean flowering time of early-flowering progenies (36, 41, 31 and 33 days, respectively) differed significantly with those of the late-flowering progenies $(56,60,56$ and 65 days, respectively). Similarly, $\mathrm{F}_{3}$ progenies of these crosses also differed significantly for mean days to maturity, with $87,90,81$ and 83 days for the respectively crosses among the early bulks and 107, 109, 103 and 109 days for the respectively crosses among the late bulks. These results provide evidence that flowering time had a positive effect on maturity, suggesting that selection for the early-flowering trait will be appropriate for developing early-maturing lines. Significant differences were found between the two bulks with respect to biomass in all of the crosses except ICC $5810 \times$ CDC Frontier, where the difference was statistically non-significant, with the mean biomass of early- and late-flowering progenies being 391 and $443 \mathrm{~g}$, respectively. The difference in grain yield of the early-flowering progenies was statistically nonsignificant from that of the late-flowering bulks in all crosses except BGD $132 \times$ CDC Frontier, where the 
Table 3 Comparison of early-and late-flowering $F_{3}$ progenies for phenology and agronomical traits in different crosses

\begin{tabular}{|c|c|c|c|c|c|c|c|}
\hline Cross & $\begin{array}{l}\text { Phenotypic } \\
\text { class }\end{array}$ & $\begin{array}{l}\text { Flowering } \\
\text { time }\end{array}$ & $\begin{array}{l}\text { Days to } \\
\text { maturity }\end{array}$ & Biomass (g) & Grain yield (g) & $\begin{array}{l}\text { Harvest } \\
\text { index }(\%)\end{array}$ & $\begin{array}{l}100 \text { Seed } \\
\text { weight }(\mathrm{g})\end{array}$ \\
\hline \multirow{7}{*}{$\begin{array}{l}\text { ICCV } \\
96029 \times \mathrm{CDC} \\
\text { Frontier }\end{array}$} & Early & & & & & & \\
\hline & Mean & 36 & 87 & 394.36 & 241.3 & 61 & 21.85 \\
\hline & Range & $30-40$ & $80-96$ & $311-530$ & $194.48-309.93$ & $50-67$ & $14.87-29.86$ \\
\hline & $\underline{\text { Late }}$ & & & & & & \\
\hline & Mean & 56 & 107 & 587.51 & 270.62 & 46 & 21.29 \\
\hline & Range & $48-66$ & $96-116$ & $466.25-801.42$ & $198.38-334.67$ & $37-57$ & $14.2-31.78$ \\
\hline & $\begin{array}{l}\text { Probability } \\
(t \text { test })\end{array}$ & $<0.005^{*}$ & $<0.005^{*}$ & $<0.005^{*}$ & $0.02 \mathrm{~ns}$ & $<0.005^{*}$ & $0.65 \mathrm{~ns}$ \\
\hline \multirow{7}{*}{$\begin{array}{l}\text { ICC } 5810 \times \mathrm{CDC} \\
\text { Frontier }\end{array}$} & Early & & & & & & \\
\hline & Mean & 41 & 90 & 391.02 & 209.12 & 53 & 21.77 \\
\hline & Range & $34-44$ & $80-96$ & $260-502.5$ & $132.58-288.36$ & $44-59$ & $16.15-30.76$ \\
\hline & $\underline{\text { Late }}$ & & & & & & \\
\hline & Mean & 60 & 109 & 443.28 & 220.50 & 43 & 25.13 \\
\hline & Range & $54-64$ & $101-115$ & $322.5-564.28$ & $161.13-284.7$ & $34-54$ & $20.03-32.48$ \\
\hline & $\begin{array}{l}\text { Probability } \\
(t \text { test })\end{array}$ & $<0.005^{*}$ & $<0.005 *$ & $0.17 \mathrm{~ns}$ & $0.46 \mathrm{~ns}$ & $<0.005^{*}$ & $0.13 \mathrm{~ns}$ \\
\hline \multirow{7}{*}{$\begin{array}{l}\text { BGD } 132 \times \text { CDC } \\
\text { Frontier }\end{array}$} & Early & & & & & & \\
\hline & Mean & 31 & 81 & 350.38 & 182.11 & 52 & 34.24 \\
\hline & Range & $30-35$ & $78-94$ & $187.5-466.66$ & $102.91-286.28$ & $25-64$ & $28.62-38.87$ \\
\hline & Late & & & & & & \\
\hline & Mean & 56 & 103 & 483.5 & 229.45 & 48 & 32.27 \\
\hline & Range & $42-66$ & $93-116$ & $318-596$ & $151.56-287.95$ & $31-64$ & $25.23-39.1$ \\
\hline & $\begin{array}{l}\text { Probability } \\
(t \text { test })\end{array}$ & $<0.005^{*}$ & $<0.005 *$ & $<0.005^{*}$ & $<0.005^{*}$ & $0.17 \mathrm{~ns}$ & $0.04 \mathrm{~ns}$ \\
\hline \multirow{7}{*}{$\begin{array}{l}\text { ICC } 16641 \times \text { CDC } \\
\text { Frontier }\end{array}$} & Early & & & & & & \\
\hline & Mean & 33 & 83 & 275.69 & 170.46 & 61 & 29.48 \\
\hline & Range & $31-35$ & $82-88$ & $177.5-367.77$ & $110.87-234.13$ & $52-66$ & $20.66-36.42$ \\
\hline & Late & & & & & & \\
\hline & Mean & 65 & 109 & 485.54 & 190.98 & 37 & 30.56 \\
\hline & Range & $41-73$ & $101-119$ & $302-580$ & $107.25-319.35$ & $21-55$ & $23.24-37.5$ \\
\hline & $\begin{array}{l}\text { Probability } \\
\text { ( } t \text { test })\end{array}$ & $<0.005^{*}$ & $<0.005^{*}$ & $<0.005^{*}$ & $.018 \mathrm{~ns}$ & $<0.005^{*}$ & $0.44 \mathrm{~ns}$ \\
\hline
\end{tabular}

*Significant difference between phenotypic class at the 0.05 level; ns, not significant

mean grain yield in early- and late-flowering bulks was 182.11 and $229.45 \mathrm{~g}$, respectively, however the maximum range of grain yield produced by early- and late-flowering bulks was 286.28 and $287.95 \mathrm{~g}$, respectively. These results indicate that given the duration of the crop, early-flowering bulks were more efficient in their yield partitioning potential, which is expressed by their higher harvest indices compared to those of the late bulks of all the crosses (Table 3). This result suggests that selection for early flowering in these genetic backgrounds need not necessarily involve a severe reduction in grain yield compared to late flowering. This trait is particularly important under short season environments where growing early varieties can stabilize yield when the crop is more prone to suffer terminal stresses. A non-significant difference between 100-seed weight of early- and lateflowering bulks was observed in all of the crosses, indicating that selection for early flowering does not pose any negative effect on seed size.

Flowering time is considered to be an important adaptive trait to various target environments. The 

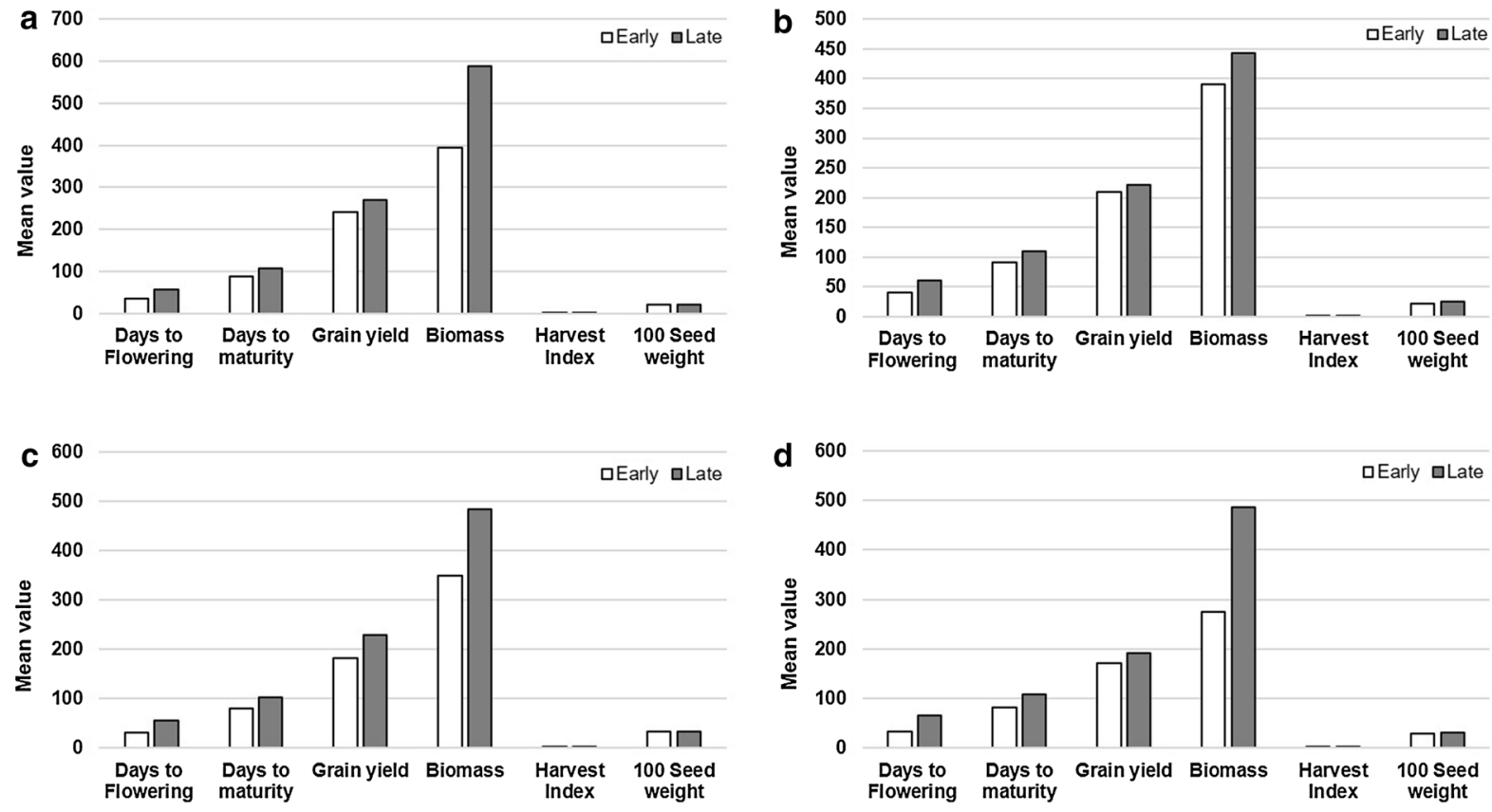

Fig. 1 Comparison between early-and late-flowering $F_{3}$ segregants for phenological and yield-related traits in different crosses. a ICCV $96029 \times$ CDC Frontier, b ICC $5810 \times$ CDC Frontier, c BGD $132 \times$ CDC Frontier, d ICC $16641 \times$ CDC Frontier

results of this study show that the early-flowering trait in suitable genetic backgrounds can produce highyielding genotypes similar to that of late-flowering or maturing genotypes under terminal drought stress conditions. This knowledge will help breeders to develop early-maturing varieties with a high yield potential for short season environments.

Acknowledgements This research work was supported by CGIAR Research Program on Grain Legumes.

Author's contributions PMG coordinated this project. PMG, KPV, SS guided BPM in planning and designing this study. BPM, PMG and SS were involved in developing the mapping populations, designing field experimentation, phenotyping and data analysis. BPM, PMG, and SS drafted the manuscript, and all the authors reviewed and approved the manuscript.

\section{Compliance with ethical standards}

Conflict of interest The authors declare that they have no conflict of interest.

\section{References}

Anbessa Y, Warkentin T, Vandenberg A, Ball R (2006) Inheritance of time to flowering in chickpea in a short-season temperate environments. J Hered 97:55-61
Anbessa Y, Warkentin T, Bueckert R, Vandenberg A, Gan Y (2007) Post-flowering dry matter accumulation and partitioning and timing of crop maturity in chickpea in western Canada. Can J Plant Sci 87:233-240

Berger JD, Turner NC, Siddique KHM, Knights EJ, Brinsmead RB, Mock I, Edmondson C, Khan TN (2004) Genotype by environment studies across Australia reveal the importance of phenology for chickpea (Cicer arietinum L.) improvement. Aust J Agric Res 55:1071-1084

Berger JD, Ali M, Basu PS, Chaudhary BD, Chaturvedi SK, Deshmukh PS (2006) Genotype by environment studies demonstrate the critical role of phenology in adaptation of chickpea (Cicer arietinum L.) to high and low yielding environments of India. Field Crops Res 98:230-244

Bonfil DJ, Lichtenzveig J, Shai I, Lerner A, Tam S, Abbo S (2006) Associations between earliness, Ascochyta response, and grain yield in chickpea. Aust J Agril Res 57:465-470

Erskine W, Kosmenuglu I, Muehlbauer FJ, Summerfield RJ (2000) Breeding for increased biomass and persistent crop residues in cool-season food legumes. In: Knight $\mathrm{R}$ (ed) Linking research and marketing opportunities for pulses in the 21st Century. Kluwer Academic Publishers, Dordrecht, pp 191-197

FAOSTAT (2016). http://www.fao.org/faostat/en/. Accessed 20 Feb 2018

Gaur PM, Kumar J, Gowda CLL, Pande S, Siddique KHM, Khan TN, Warkentin TD, Chaturvedi SK, Than AM, Ketema D (2008a) Breeding chickpea for early phenology: perspectives, progress, prospects. In: Kharkwal MC (ed) Food legumes for nutritional security, sustainable 
agriculture, vol 2. Indian Society of Genetics, Plant Breeding, New Delhi, pp 39-48

Gaur PML, Krishnamurthy L, Kashiwagi J (2008b) Improving drought-avoidance root traits in chickpea (Cicer arietinum L.), Current status of research at ICRISAT. Plant Prod Sci 11:3-11

Gaur PM, Samineni S, Tripathi S, Varshney RK, Gowda CLL (2015) Allelic relationships of flowering time genes in chickpea. Euphytica 203:295-308

Gaur PM, Samineni S, Thudi M, Tripathi S, Sajja SB, Jayalakshmi V, Mannur DM, Vijayakumar AG, Ganga Rao NVPR, Ojiewo C, Fikre A, Kimurto P, Kileo RO, Girma N, Chaturvedi SK, Varshney RK, Dixit GP (2018) Integrated breeding approaches for improving drought and heat adaptation in chickpea (Cicer arietinum L.). Plant Breed. https://doi.org/10.1111/pbr.12641

Hegde VS (2010) Genetics of flowering time in chickpea in a semi-arid environment. Plant Breed 129:683-687

Hovav R, Upadhyaya KC, Beharav A, Abbo S (2003) Major flowering time gene and polygene effects on chickpea seed weight. Plant Breed 122:539-541

Jukanti AK, Gaur PM, Gowda CLL, Chibbar RN (2012) Nutritional quality and health benefits of chickpea (Cicer arietinum L.): a review. Brit J Nutr 108:S11-S26

Kumar J, Abbo S (2001) Genetics of flowering time in chickpea and its bearing on productivity in semi-arid environments. Adv Agron 72:107-138

Kumar J, van Rheenen HA (2000) A major gene for time of flowering in chickpea. J Hered 91:67-68

Mallikarjuna BP, Samineni S, Thudi M, Sajja SB, Kahn AW, Patil A, Viswanatha KP, Varshney RK, Gaur PM (2017) Molecular mapping of flowering time major genes and
QTLs in chickpea (Cicer arietinum L.). Front Plant Sci 8:1140

Or E, Hovav R, Abbo S (1999) A major gene for flowering time in chickpea. Crop Sci 39:315-322

Siddique KHM, Khan TN (1996) Early-flowering and high yielding chickpea lines from ICRISAT ready for release in Western Australia. Int Chickpea Pigeonpea Newsl 3:22-24

Sivasakthi K, Thudi M, Tharanya M, Kale SM, Kholova J, Halime MH, Jaganathan D, Baddam R, Thirunalasundari T, Gaur PM, Varshney RK, Vadez V (2018) Plant vigour QTLs co-map with an earlier reported QTL hotspot for drought tolerance while water saving QTLs map in other regions of the chickpea genome. BMC Plant Biol 18:1-18

Slinkard AE, Sindhu JS (1988) Role of physiology in pulse crop improvement: a plant breeding perspective. In: Summerfield RJ (ed) World crops: cool season food legumes. Kluwer Academic, Dordrecht, pp 931-939

Subbarao GV, Johansen C, Slinkard AE, Rao RCN, Saxena NP, Chauhan YS (1995) Strategies for improving drought resistance in grain legumes. CRC Crit Rev Plant Sci 14:469-523

Wallace DH, Zobel RW, Youstone KS (1993) A whole-system reconsideration of paradigms about photoperiod and temperature control of crop yield. Theor Appl Genet 86:17-26

Warkentin T, Banniza S, Vandenberg A (2005) CDC Frontier kabuli chickpea. Can J Plant Sci 85:909-910

Publisher's Note Springer Nature remains neutral with regard to jurisdictional claims in published maps and institutional affiliations. 